\title{
The Patriarchy System as the Trigger of Sexual Coercion in The Novel Moxie By Jennifer Mathieu
}

\author{
Nurliani \\ Balikpapan University \\ nurlianiuniba@yahoo.com \\ Rosmiati \\ Balikpapan University \\ rosmiati@uniba-bpn.ac.id \\ Adi Prautomo \\ Balikpapan University \\ adi.prautomo@uniba-bpn.ac.id
}

\begin{abstract}
:
This research analysed how the patriarchy system acts as the trigger of sexual coercions as reflected in the novel Moxie by Jennifer Mathieu. The objectives of this research are 1) to determine the forms of sexual coercion in the novel Moxie; and 2) to determine how the patriarchy system triggers sexual coercions in the novel Moxie. The researcher used Alison M. Jaggar's radical feminism theory as the main theory and Smuts and Smuts' theory of sexual coercion as the supporting theory in analyzing the collected data. Jaggar's radical feminism theory is used to analyze how the patriarchy system triggers sexual coercion while Smuts and Smuts' theory is used to analyze the forms of sexual coercion. The research methodology of this research is qualitative descriptive; in which the relevant data were collected from the text found in the novel Moxie. This research resulted with direct coercion such as sexual harassment, intimidation, and rape as the form of sexual coercions found in the novel Moxie. This research also resulted with patriarchal ideology and patriarchal stereotypes being the triggers of direct coercion in patriarchal society.
\end{abstract}

Keywords Patriarchy, Sexual Coercion, Radical Feminism 


\section{INTRODUCTION}

Human consists of men and women. Both of them are different creatures defined by the sexes, but connected with each other as social beings which live in society. In society, men are often considered as the leader while women are the followers. It happens because the society describes men as strong and rational while women are weak and emotional. The human lives as a man and woman are often inspired the creator content such as author, cinematography, or even an artist to create a work which represents their life. The one who often produces a work about human lives is an author which describes it through literature.

Literature is defined as "anything that is written" (Bressler, 2007, p. 12). It is also an art which has moral values in life illustrated through stories such as in short stories, novels, or dramas. In a novel, the plot tells the relationship between men and women are often illustrated as more complicated than in other literary works. It is stated by Abrams, a novel is "magnitude permits a greater variety of characters, greater complication of plot (plots) (1999, p. 190)." The researcher explained the complicated relationships between the sexes are often inspired from their life in a society which roots in the assumption that women are objects while men are subjects. Those assumptions often make women subordinate and suffer. It is illustrated in the novel entitled Moxie as one example of literature.

Moxie is a novel written by an American author named Jennifer Mathieu. The novel tells about teenage life at a high school in a small town Texas, United States named "East Rockport High School." The East Rockport High School is a typical American High School where there is a lot of male culture that rule and dominate the school.

The researcher is interested in analyzing the novel Moxie because it has a relationship with one of the branches in feminism which is radical feminism. Both of them are connected with each other because the novel tells about a male culture and radical feminism also talks about it which is known as patriarchy. As stated by Jaggar, "Radical feminism sees patriarchy as a total system, a male culture characterized by violence, domination and death. The male culture manifests itself in every aspect of life (1983, p. 283)." The researcher identifies the patriarchy system or male culture is a culture by men and harm for women because it is often used violence and domination against women. It is also a system which illustrates in every aspect of life, such as in literature especially novel.

The male culture or the patriarchy system illustrated in the novel Moxie through the actions of the male students, especially the football team who rules the school and also treats the female students badly like an object from the jokes, gross comment and T-shirts, the game, and many more. The male students and even the school administrations which mostly male suggested that the female students can take it as a "compliment." The school never condemns and punishes the male students like nothing happened, especially because the male students on the football team who is so dominant in the town.

The researcher described the society in the novel Moxie illustrates as patriarchal. In line with radical feminism which also describes society as patriarchal. As stated by Ramazanoglu, "Radical feminists also successfully used the conception of patriarchy to challenge conventional knowledge of society as patriarchal, that is, as constructed by men 
in men's interests (1989, p. 35)." It means, the concept of patriarchal society is just to fill the need of men and then men ignored other people like women. In patriarchy, the system of the patriarchal society is rooted in patriarchal ideology. In patriarchal ideology, women are subordinate while men are dominant and there is a patriarchal stereotype which usually makes women suffer because it defines women inappropriate such as women are the sexual object of men. Men use women for their own need and interest which often lead to the acts of men which harm for women such as sexual harassment, abuse, assault, rape, violence, or even murder. It is as reflected in the novel Moxie, where the female students are often suffering from harassment, attempt of rape, etc. All of those acts usually begin through the sexual coercion by men against women.

In this research, sexual coercion which happens through patriarchy system is the topic that the researcher interested to analyze. According to Madsen, "Sexual coercion work within the context of patriarchy as a system that operates through 'persons, institutions, and values' (2000, p. 162)." Therefore, the researcher identifies the patriarchy system as the trigger of sexual coercion. It is as reflected in the novel Moxie the sexual coercion happens within the context of patriarchy through the male students in institution which is school.

This research focused to analyze the patriarchy system as the trigger of sexual coercion in the novel Moxie by Jennifer Mathieu. The researcher used radical feminism by Alison M. Jaggar and supporting theory by Smuts and Smuts to analyze this research. Based on the explanation above, the title of this research is "The Patriarchy System as The Trigger of Sexual Coercion in the Novel Moxie by Jennifer Mathieu."

\section{LITERATURE REVIEW}

\section{Feminism}

Feminism is a theory about women's right. It is also a women's movement and women's study which learned and observed about the women's lives in society. Feminism concerned with the issues or the problem in women's lives. According to Jaggar, feminism is stated below:

"Feminism" was originally a French word. It referred to what in the 19th-century United States was called "the woman movement": a diverse collection of groups all aimed, in one way or another, at "advancing" the position of women. (1983, p. 5)

The researcher identifies from the statement above the term feminism had already emerged from a long time ago. The movement emerged because of the women's position, situation and reality in society are not really as important as men. The position of women in society is different from each other some of them are mothers, wives, teenagers, and child. Women are put in home while men are put in the public. Women are seen as inferior or subordinate. In line with Jaggar, "In a sense, feminism has always existed, certainly, as long as women have been subordinated, they have resisted that subordination $(1983$, p. 3)." Therefore, from 
those problems of women's lives feminism are emerged as the information and also give solution to liberate women from the problems they faced.

Feminism always emerged as long as women are subordinate. Based on the difference from the point of view in seen the women's subordination, feminism has many branches such as liberal feminism, radical feminism, Marxist and socialist feminism, and existentialist feminism. The subordination of women in the feminism branches is different from each other but they emerged because of the system called "patriarchy". Patriarchy is a system in society which rule by men.

\section{Radical Feminism}

Radical feminism is one of the branches in feminism. As the part of feminism theory, radical feminism absolutely talks about women. According to Jaggar, radical feminism is "a contemporary phenomenon generated by the women's liberation movement of the late 1960s (1983, p. 83)." Based on the statement by Jaggar, radical feminism is the part of women's liberation movement in the contemporary society. "On the radical feminist view, contemporary society is a patriarchy (Jaggar, 1983, p. 255)." It means society follows a system known as patriarchy.

\section{Patriarchy}

Patriarchy means "the rule of society and culture by men (Bressler, 2007, p. 167-168)." The researcher describes patriarchy as a system in society because it consists of rules and cultures of men and system is also means a set of rules. As a system, patriarchy puts men as the ruler and women as the follower also men as the subjects while women are the objects. It means it all about men. Through patriarchy, men rule other men, women, and also children. Moreover, women are the one who usually suffer from the system of patriarchy.

The relationship between radical feminism and patriarchy is seen in the quotation "Radical feminism sees patriarchy as a total system, a male culture characterized by violence, domination and death. The male culture manifests itself in every aspect of life (Jaggar, 1983, p. 283)." The researcher identifies the patriarchy system or male culture is a culture by men and harm for women because it is often used violence and domination against women. It is also a system which illustrates in every aspect of life.

In patriarchy system, the characteristic of their society is known as patriarchal society, as seen in the quotation "Radical feminists also successfully used the conception of patriarchy to challenge conventional knowledge of society as patriarchal, that is, as constructed by men in men's interests (Ramazanoglu, 1989, p. 35)." From the explanation, the researcher identifies that the concept of patriarchal society is just to fill the need of men and then men ignored other people such as women and also children. In patriarchy, the system of the patriarchal society is rooted in patriarchal ideology. In patriarchal ideology, women are subordinate by society or men and there are patriarchal stereotype which usually makes women suffer because it defines women inappropriate such as women are the sexual object of men. Men use women for their own need and interest and they never think about the women. As long as the women complete the men need they will be fine. 
Patriarchal society used their ideology to differ men and women. "Patriarchal ideology exaggerates biological differences between men and women, making certain that men always have the dominant, or masculine, roles and women always have the subordinate, or feminine, ones (Tong, 2009, p. 52)." The researcher identifies from the statement, it can be seen that men are dominant or the subject while women are subordinate or the object. It means the differences between men and women are the source of women's subordination because it makes men dominate women.

According to Jaggar, women's subordination is as seen below:

Women are kept in subordination by direct physical coercion, coercion which is sometimes seen as resulting from innate male aggression. In western society, this coercion is institutionalized through rape and battery; in other societies, by other means. (1983, p. 104)

Based on the statement, it explained that women are subordinated by using a direct physical coercion such as rape or etc. The direct physical coercion is really cruel for the victim especially women because women and men are different in the body structure.

The direct physical coercion such as raped is really often occurs in society especially in patriarchy, as explained below:

Rape may not have existed in every society, but it is a defining feature of patriarchy. . . Overtly, patriarchal ideology condemns rape; covertly, it legitimizes rape by viewing it as normal. (Jaggar, 1983, p. 261)

From the explanations above, it explains rape is violent because it is mostly used physical coercion to the victim. Rape also cruel because it is often left the trauma to the victims but in patriarchy system it is seen as normal. In line with Jaggar, patriarchal ideology "defines women in a way specific to their sex, as beings whose special function is to gratify male sexual desires (1983, p. 255)." It means because of patriarchal ideology, women are just a female who gives birth to a baby and women's lives as only to satisfy the male sexual desire.

Patriarchy or the male culture defines women based on her sexuality also makes women as the sexual object of men, as explains below:

The male culture defines women as sexual objects for male pleasure. For much of her life, every woman is evaluated continuously in those terms. . . If she is young, whatever she does is interpreted in sexual terms; she cannot avoid either reinforcing or challenging the patriarchal stereotype of women as sexual objects. (Jaggar, 1983, p.260)

Based on the explanations above, it explains that women are the sexual object of men because the patriarchal stereotypes make them that way and it cannot be eliminated. It can be said that whatever women does it always interprets in a sexual way by men. The 
patriarchal stereotype of women as sexual object of men mostly happens to young women. It seen that patriarchy are blame women for they behavior, lives, etc and it just defined women as the sexual object of men. Whatever women do and whatever women wear it always seen in the sexual terms. The conditions of women from the sexual object most of them used or begin with sexual coercion.

\section{Sexual Coercion}

Sexual coercion means a force of someone against another one and in this research it is men who forces women in the sexual contexts. As stated by Smuts and Smuts' (as cited in Muller and Wrangham, 2009) sexual coercion is "use by a male of force, or threat of force, that functions to increase the chances that female will mate with him." The researcher describes that sexual coercion happens when man forces woman to engage in sexual activity or to mate with him.

There are two forms of sexual coercion, direct coercion and indirect coercion. Direct coercion, "involves the use of force to overcome female resistance to mating" (Muller and Wrangham, 2009, p. 10). The researcher describes direct coercion happen when man forces woman directly to engage in sexual activity in order for the woman cannot reject or refuse it.

Clutton-Brock and Parker (as cited in Muller and Wrangham, 2009) explains there are three types of direct coercion: "first is raped involves violent restraint, second is harassment involves repeated attempts to mate, and third is intimidation involves physical retribution against female refusals to mate."

Indirect coercion, according to Smuts and Smuts's (as cited in Muller and Wrangham, 2009) is "the use of force to decrease the chances that [a female] will mate with other males." The researcher describes that indirect coercion happen when man manage woman with force to engage in sexual activity with him rather that with other men. There are also three types of indirect coercion by Smuts and Smuts's: "first is herding which involves short-term aggression directed toward females, second is punishment which involves physical retribution against female, and third is sequestration which involves forceful separation of females from a social group."

However, both forms of sexual coercion such as direct coercion and indirect coercion are happen not only in human but also in nonhuman such as primates. It is the idea which a researcher can use to analyze a research about sexual coercion in a literary work and also in real life or real world. In line with Muller and Wrangham (2009), "The application of this idea to different contexts, whether to different populations or different species, represents an exciting opportunity for understanding coercion in both humans and nonhuman primates (p. 18)." In this research, the researcher used the theory of sexual coercion by Smuts and Smuts's as the supporting theory to find the form of sexual coercion toward women in the novel object.

The previous study of this research is entitled the longing of a woman to get free from the influence of patriarcism a feminism approach to the novel "Inside The Kingdom" by Carmen Bin Laden by Lisa Marten from Balikpapan university, Balikpapan (2008). Her 
research is aimed to analyze the influence of patriarchy to major character and the patriarcism form on the novel Inside The Kingdom by Carmen Bin Laden. The similarity between her research and this research are analyzed about patriarchy with radical feminism theory. The differences first is the novel object, second, is the radical feminism theorist she used the theory by Shulamith Firestone while this research used theory by Jaggar, and third, is the result of the research she found the failure of woman rights, class oppression, woman's subordination and this research found the form of sexual coercion which is direct coercion and the patriarchy system as the trigger of sexual coercion is through patriarchal society.

\section{RESEARCH METHODOLOGY}

The type of this research is qualitative descriptive research. In this research, the sources of the data are divided into two parts, primary and secondary. The primary data of this research is the texts on the novel entitled Moxie by Jennifer Mathieu. The secondary data of this research are taken from the library research such as books, journals, articles, and from the internet. The data collection procedures of this research are based on the qualitative research. First, the researcher determined the object of this research. Second, the researcher chooses a novel entitled Moxie by Jennifer Mathieu to be the object of this research. Third, the researcher reads the novel object and focus to find the problems. Fourth, the researcher determined the problems on the novel which the researcher analyzed. Fifth, the researcher related the problems on the novel with the relevant theory. Sixth, use radical feminism theory by Jaggar and the supporting theory by Smuts and Smuts to analyze the novel object. The last is analyzed and interpreted the novel object and then makes a conclusion.

\section{FINDINGS AND DISCUSSION}

In this section, the researcher discussed the findings of this research which are forms of sexual coercion and how the patriarchy system triggers sexual coercion as found in the novel Moxie. The researcher interpreted the relevant data taken from the text in Moxie and analyzed them with Alison M. Jaggar's radical feminism theory along with the Smuts and Smuts' theory of sexual coercion as the supporting theory of this research.

\section{Forms of Sexual Coercion}

\section{Direct Coercion}

The researcher found three types of direct coercion in the novel, they are: sexual harassment, intimidation, and rape.

\section{Sexual Harassment}

Sexual harassment is the first type of direct sexual coercion found in the novel Moxie. As stated in the theoretical review, the researcher characterized harassment as repeated acts of a man who directly forces women to engage in sexual activities with him. The researcher 
found several excerpts containing sexual harassment done by the male students against the female students of East Rockport High School.

\section{Physical Sexual Harassment}

The first form of sexual harassment found in the novel Moxie is physical sexual harassment. This form of sexual harassment is manifested through the actions of the male students against the female students of East Rockport High School.

You know that hallway, right outside of the locker room?' . .

- 'Well, Mitchell walks up to me, just, like, comes right at me, and does that fucking bump ' $\mathrm{n}$ ' grab bullshit,' she says. 'Only ... . when he grabs me, he just, like, pins me up against the wall and he actually slides his hand up under my shirt. And he, like ...' She pinches up her face, wincing. 'He, like, grabbed me. Grabbed one of my breasts and squeezed it.' (Mathieu, 2017, p. 196-197)

The researcher chooses the excerpt above as it illustrates physical sexual harassment as told in the novel. The excerpt above is a dialogue between the characters Vivian and Claudia, in which Claudia told Vivian about the sexual harassment she experienced at the school hallway outside the locker room when she met Mitchell, one of the male students of East Rockport High School. The form of physical sexual harassment Claudia experienced is termed "bump and grab", where Claudia is pinned against a wall and have her breast groped by Mitchell. Because of the harassment, Claudia was shocked and in tears when she told the incident to Vivian.

\section{Verbal}

The second sexual harassment found in the novel Moxie is verbal sexual harassment. This type of sexual harassment is manifested through the comments made by the male students against the female students of East Rockport High School.

"Oh, shit, look at what he has on, 'Claudia mutters. Another one of his gross shirts.' Under his football jersey, Jason is wearing a white $\mathrm{T}$-shirt with big black letters. It reads GREAT LEGS - WHEN DO THEY OPEN? (Mathieu, 2017, p. 29)

The excerpt above is another dialogue between the characters Claudia and Vivian during a football game. Claudia told Vivian to look at Jason's shirt which has sexual comment against women written on it. The words written on Jason's shirt read "GREAT LEGS WHEN DO THEY OPEN?" is classified by the researcher as a form of verbal sexual harassment as these words indicate explicit meaning by men against women. The sexual comment on Jason's shirt means that a man adores a woman's legs solely just so the woman would engage in sexual activities with him. 


\section{Intimidation}

The second type of direct sexual coercion found in the novel Moxie is intimidation. As stated in the theoretical review, intimidation happens when a man uses physical retribution to the woman who refuses his sexual proposition. The researcher found intimidation in the following excerpt:

'I told him to stop it. That he was hurting me. And he just, like, laughed off, you know? He just made me stand there like that for what felt like forever, just pawing at me. I could feel his hot breath on my neck. And it hurts. It hurts so much.' . . . 'How did you get away?' I ask. Claudia closes her eyes. 'I didn't. He just stopped, eventually. And he, like, walked off.' Her brown eyes open, and she looks at me again. 'And you know what was so creepy? While he was messing with me, he had this look on his face. This dead look. Like I could have been anyone. Or anything.' (Mathieu, 2017, p. 197)

The excerpt above is a follow-up dialogue between Vivian and Claudia after the bump and grab incident. Mitchell did the bump and grab to Claudia so that she would engage in sexual activities with him only for her to refuse by telling him to stop grabbing her breast because it hurt her. He then intimidated her staring at her and giving her a dead look as he walked away from her.

The researcher classifies the above excerpt as a form of intimidation by a man against a woman. It shows that Claudia got intimidated by Mitchell after telling him to stop grabbing her breast. Mitchell intimidated her by giving her a dead look in his eyes which indicates how angry she was at her for refusing to engage in a sexual activity with him.

\section{Rape}

Rape is the third type of direct sexual coercion found in the novel Moxie. As stated in the theoretical review, rape happens when a man uses physical force and violence against a woman to engage in a sexual activity with him. The researcher found an excerpt indicating attempted rape by a male student against a female student in the novel Moxie.

\section{MOXIE WALKOUT!!! THIS FRIDAY. AT THE}

ATTENDANCE BELL. I am tired of being silent. Mitchell

Wilson tried to rape me at a party. I won't be quiet anymore. Principal Wilson and the administration of erhs refused to listen to me, if you support this walkout you support all girls, you support a movement. That refuses to tolerate. Violence against girls. (Mathieu, 2017, p. 289)

The excerpt above showed words in a flyer spread anonymously at East Rockport High School. Despite made anonymously, it is clear to the researcher that the flyer was made by a girl. The flyer contained an invitation for the female students to walk out of class on Friday at the attendance bell. The flyer indicated that someone who made it was tired of 
being silent and quiet because she was almost raped by Mitchell Wilson at a party last week. She tried to tell the principal and the school administration but they did not listen to her. From the researcher's description, the researcher classifies the above indication as a type of direct coercion that is rape. The words in the flyer indicates that a female student of East Rockport High School was almost raped by a male student named Mitchell.

\section{Patriarchy System Triggering Sexual Coercion}

1. Patriarchal Ideology

Patriarchal ideology makes men as the dominant ones or subjects while women are subordinates or mere objects. This ideology also makes the life purpose of women is to satisfy the sexual desires of men. Therefore, the researcher concluded that the patriarchal ideology as one of the triggers of sexual coercion in the novel Moxie.

a. Patriarchal Ideology Triggers Sexual Harassment

How the patriarchal ideology triggers sexual harassment can be seen in the following excerpt:

It feels so good to tag Mitchell's locker first. . . . I think about Claudia. I think about how humiliated and angry and hurt she was in that empty hallway. I think about Mr. Shelly telling her to forget about it. I think about Mitchell's ruddy face and dead eyes. I think about his daddy letting him do anything he wants. (Mathieu, 2017, p.209-210)

The excerpt above is from when Vivian started to protest again the sexual harassments done by the male students of East Rockport High School through the Moxie movement. Angered Vivian made stickers and distributed them to all of the female students who are fed up of the sexual harassment in their school.

From the excerpt above, the researcher concluded that the school is dismissive of sexual harassments. As seen in the line "I think about his daddy letting him do anything he wants", it means that a man can do anything they want such as sexually harassing women because of the patriarchal ideology that makes women subordinate to men. Mitchell is the son of the principal, meaning that he holds dominance at school so he can do whatever he wants such as sexually harassing the female students.

Moreover, how the patriarchal ideology triggers verbal sexual harassment can be seen in the following excerpt:

Jason is wearing the shirt in front of Coach Cole and Principal Wilson, but it won't matter. He can get away with it. He always gets away with shirts like these, and he's not the only boy in school who like wearing them. Boys being boys or whatever. (Mathieu, 2017, p. 29)

The excerpt above is Vivian's thoughts about how Jason, a male student, got away with wearing a shirt with sexual comments against women on it. The researcher concluded that patriarchal ideology runs deep in which the school's higher-ups blatantly ignored 
the obvious verbal sexual harassment towards women written on a shirt. This ignorance is rooted from the patriarchal ideology that makes women subordinate to men.

b. Patriarchal Ideology Triggers Rape

How patriarchal ideology triggers rape in the novel Moxie can be seen in the following excerpt:

Of course, it's all anyone can talk about. But weirdly, East Rockport almost feels quieter than normal. Because people are so stunned by the flyer that they are whispering, speaking in hushed voices. Not even opening their mouths so much as staring at each other with can-you-believe-it? looks in their faces. (Mathieu, 2017, p. 290)

The excerpt above showed the condition at East Rockport High School after the walkout to protest violence against women invitation flyer was distributed. It was then revealed that the flyer was made by Emma, the vice president, who was almost raped by Mitchell, the principal's son and football player that ruled the school. Despite the truth coming out, the situation at school remained normal as if nothing happened; nobody really cared nor believe what was written in the flyer. The researcher concluded from the excerpt that the patriarchy system triggers sexual coercion because East Rockport High School that follows patriarchal ideology perceive rape as something normal.

\section{PATRIARCHAL STEREOTYPE}

\section{PATRIARCHAL STEREOTYPE TRIGGERS SEXUAL HARASSMENT}

2. Patriarchal Stereotype

a. Patriarchal Stereotype Triggers Sexual Harassment

How the patriarchal stereotype triggers sexual harassment in the novel Moxie can be seen in the following excerpt:

I went to see Mr. Shelly.' Mr. Shelly, one of the assistant principals. . . . Principal Wilson's right-hand man. ... 'Well, I went into his office,' Claudia says. 'I still can't believe I did that. Maybe I was just operating on autopilot. I don't know. But I went in there and I told him, well ... I didn't go into the details, exactly. I just told him Mitchell had done the bump 'n' grab game to me and it upset me.' 'He looked at me and told me that Mitchell was probably just joking and that I should take the break to relax and forget about it,' Claudia answers. She's not crying anymore. She's just still. Mad. 'And then he said I should probably take it as a compliment.' (Mathieu, 2017, p. 198)

The excerpt above is a dialogue between Vivian and Claudia when Claudia had been sexually harassed by Mitchell. Though Claudia initially hesitated whether or not she should tell the school about it, she eventually told the school administrator Mr. Shelly. 
After telling him how the bump and grab game hurt her, Mr. Shelly told Claudia that it was just boys being boys and that it was nothing more than a game. He even suggested her to take a break just forget about it and told her to take it as a compliment because Mitchell was a popular guy at East Rockport High School.

The researcher concluded from the above excerpt that Claudia's sexual harassment took place due to the patriarchal stereotype of women being perceived as mere sexual objects to men. It can be seen that East Rockport High School is ruled under the patriarchy system. As seen in the excerpt, Claudia's sexual harassment report was being dismissed and she was told to take it (the sexual harassment) as a compliment.

b. Patriarchal Stereotype Triggers Intimidation

How patriarchal stereotype triggers intimidation in the novel Moxie can be seen in the following excerpt:

I went to see Mr. Shelly.' Mr Shelly, one of the assistant principals. .. . Principal Wilson's right-hand man. . . 'Well, I went into his office,' Claudia says. 'I still can't believe I did that. Maybe I was just operating on autopilot. I don't know. But I went in there and I told him, well . . . I didn't go into the details, exactly. I just told him Mitchell had done the bump 'n' grab game to me and it upset me.' 'He looked at me and told me that Mitchell was probably just joking and that I should take the break to relax and forget about it,' Claudia answers. She's not crying anymore. She's just still. Mad. 'And then he said I should probably take it as a compliment.' (Mathieu, 2017, p. 198)

The excerpt above is a dialogue between Vivian and Claudia when Claudia had been sexually harassed by Mitchell. Though Claudia initially hesitated whether or not she should tell the school about it, she eventually told the school administrator Mr. Shelly. After telling him how the bump and grab game hurt her, Mr. Shelly told Claudia that it was just boys being boys and that it was nothing more than a game. He even suggested her to take a break just forget about it and told her to take it as a compliment because Mitchell was a popular guy at East Rockport High School.

The researcher concluded from the above excerpt that Claudia's intimidation took place due to the patriarchal stereotype of women being perceived as mere sexual objects to men. It can be seen that East Rockport High School is ruled under the patriarchy system. As seen in the excerpt, Claudia's report of intimidation was dismissed and she was told to take it (the intimidation) as a compliment.

c. Patriarchal Stereotype Triggers Rape

How the patriarchal stereotype triggers rape in the novel Moxie can be seen in the following excerpt:

Emma squeezed her eyes shut, collects herself, then continues. 'I was able to get away. But then later when I tried 
to tell Principal Wilson, he wouldn't listen. He told me that I'd imagined it! That it was nothing and to forget it. (Mathieu, 2017, p. 316)

The excerpt above is when Emma told the female students who walked out to protest what had happened to her. She told them that Mitchell assaulted her at a party and that the principal refused to listen to her when she told him about it. Principal Wilson thought that it was just Emma's imagination because he thought that his son Mitchell was a popular guy, so he thought that a lot of female students would imagine that that'd happen to them like it was nothing and told her to forget about it.

The researcher concluded from the excerpt above that when sexual coercion such as an attempted rape happened in a patriarchal society, nobody would bat an eye and see it as something normal due to the patriarchal stereotype that women are sexual objects to men. Consequently, when a rape victim reports the crime to the authorities, the authorities would instead tell the victim that she might've just imagined it and tell her to forget about it as if it was nothing serious. Therefore, sexual coercion such as rape happens due to the patriarchal stereotype of women being the sexual objects of men.

\section{CONCLUSION}

Based on the findings and discussion in the previous chapter, the researcher found one form of sexual coercion which is direct coercion. There are three types of direct sexual coercion, first is sexual harassment in the form of physical and verbal, second is intimidation, and third is rape. In conclusion, the form of sexual coercion which is direct coercion is mostly on the type of sexual harassment in the form of physical. The patriarchy system trigger the sexual coercion is through patriarchal society, that is the patriarchal ideology and patriarchal stereotype which triggers sexual harassment, intimidation, and rape.

The researcher concludes the patriarchy system is one of the triggers which can trigger a sexual coercion against women. In patriarchy system, society is seen as patriarchal and there are patriarchal stereotype and patriarchal ideology. The researcher found that patriarchal ideology which makes women subordinate by men also viewing rape as normal and patriarchal stereotype viewing women as the sexual objects of men can trigger a sexual coercion against women in the form of direct coercion such as sexual harassment, intimidation, and raped. Therefore, the researcher found through this research that women are the ones who usually suffer in the patriarchy system.

\section{References}

Abrams, M.H (1999). A Glossary of Literary Terms ( $7^{\text {th }}$ ed.). Massachussets: Heinle \& Henle Thomas Learning.

Bressler, E. Charles. (2007). Literary Criticism: An Introduction to Theory and Practice $\left(4^{\text {th }}\right.$ ed). New Jersey: Pearson Education, Inc. 
Jaggar, M. Alison. (1983). Feminist Politics and Human Nature. United States of America: Rowman \& Allanheld Publishers.

Karimah, M. I. Virgi. (2017). The main character's resistance to patriarchal ideology in Golden Web novel Published thesis, State Islamic University Of Syarif Hidayatullah, Jakarta, Indonesia.

Klare, Mario. (2004). An Introduction To Literary Study (2 $2^{\text {nd }}$ ed). London: Routledge.

Lewis, Jane \& Ritchie, Jane. (2003). Qualitative Research Practice. India: Sage Publications.

Madsen, L. Deborah. (2000). Feminist Theory and Literary Practice. London: Pluto Press.

Marten, Lisa. (2008). The longing of a woman to get free from the influence of patriarcism a feminism approach to the novel "Inside The Kingdom" by Carmen Bin Laden Unpublished thesis, Balikpapan University, Balikpapan, Indonesia.

Mathieu, Jennifer. (2017). Moxie. London: Hodder Children's Books.

Muller, N. Martin \& Wrangham, W. Richard. (2009). Sexual Coercion In Primates and Humans: An Evolutionary Perspective on Male Aggression against Females. USA: Harvard University Press.

Pratiwi, S, Bella. (2018). The Oppression of Gender Inequality to the Women in the Novel Woman at Point Zero by Nawal El Sadawi Unpublished thesis, Balikpapan University, Balikpapan, Indonesia.

Ramazanoglu, Caroline. (1989). Feminism And The Contradictions of Oppression. London: Routledge.

Sugiyono. (2005). Metode Penelitian Kualitatif. Bandung: Alfabeta.

Tong, R. Putnam. (2009). Feminist Thought: A More Comprehensive Introduction $\left(3^{\text {rd }} \mathrm{ed}\right)$. USA: Westview Press. 